\title{
Scaffolds and Tissue Engineering
}

\author{
Gangapatnam Subramanyam ${ }^{1 *}$, Pasupuleti Sreenivas Rao², Kandappa Himakar Reddy ${ }^{2}$ and Mahaboob V \\ Shaik $^{1}$ \\ ${ }^{1}$ Research Director, Advance Research Center (ARC) Narayana Medical College Nellore, India \\ ${ }^{2}$ Scientist ARC Advance Research Center (ARC) Narayana Medical College Nellore, India
}

Submission: April 25, 2018; Published: June 22, 2018

*Corresponding author: Gangapatnam Subramanyam, Research Director, Advance Research Center (ARC) Narayana Medical College Nellore, India, Email: director.nmch@gmail.com

\section{Introduction}

Scaffold is a commonly used term for a supporting structure. Similarly scaffolds biologically are extra cellular matrix that support and keep the cells viable by nutritional supply, receptor stimulation and signaling pathways. National foundation in 1998 has coined the term tissue engineering. Tissue engineering is concerned with the development of various biological tissues as an alternative functioning to the normal tissues. Accordingly tissue engineering may be defined as the development of scaffolds or materials with in the cells for the repair of damaged organs or tissue. Tissue engineering assists for the development of structures like vessels, bladder, liver, pancreas skin and muscle etc. Scaffolds are either biodegradable or bio stable. Bio degradable scaffolds highly porous and acts as base or seeding of cells and for growth of tissues and vessels. 3D bio degradable scaffolds are preferable than 2D as the earlier mimics natural environment and a steady state like that of tissues organs. However vascular tissues like bone and cartilage are also developed by tissue engineering.

\section{Tissue engineering and stem cells}

Bone marrows contain adult stem cells haemopoitic stem cells (Hscs) and mesenchymal stem cells (Mscs). Hscs have shown the ability to give rise to haemopotic cell lineage like red blood cells. Mesenchymal cells provide all connective tissue lineage including bone, cartilage, muscle, tendon, fat, and dermls [1].

The human embryonic stem cells was definitely influenced by scaffolds under culture conditions and growth factor such as retinoic acid (RA), transforming growth factor (TGF $\beta$ ) activin A, and insulin like growth factor (IGF-1). Retinoic acid supplementation leads to neural tissue, TGF beta cartilage, activin A liver and IGF liver tissue. This holds promise for the growth of human tissue in vitro through use of human embryonic stem cells (h ESC) and biodegradable polymeric scaffolds [2]. Blood vessels are seen in the interval structure of scaffold. Park et al. [3] reported the use of PGA fibrous scaffolds as a carrier for mesenchymal stem cells and implanted into evolving infracted cavities of mouse brains. Neuronal differentiation and neuronal out growth occurred in damaged neural tissue. This offers a promise for the repair neural damaged tissue during stroke or Parkinson's disease. Mesenchymal stem cells in biodegradable material the phenyl ester of hyaluronan in the presence of TGF beta resulted in cartilaginous like tissue. lisignoll et al. [4] processed silk such as silk fibrin has been investigated as scaffolding material using h MSCs and estrogenic response was seen Kim et al. [5].

Ovine bone marrows derived mesenchymal stem cells aspirated from sternum of adult sheep have been seeded on to a PGA/ poly 4 hydroxy butyrate (p4ha) composite scaffold to generate heart valves [6]. 3D scaffolds acts as extra cellular matrix minimickins micro environment and signal transduction and gene regulation.

A bladder fabricated from polyglycolic acids coated with polylactic co-glycolic acid (PLGA) was used as a structural template [7] bladder urothelial and smooth muscle cells harvested from canine subjects were seeded on to 3D scaffolds and then cultured in vitro the same is transplanted after removal of the bladder in the animal and it has a good functional capacity. Similarly clinical application was done a composite collagen and poly glycolic acid 3D scaffold added with patients over urothelial and smooth muscle cells was successfully implanted into seven patients with a 4 years follow up [8]. Decellularised donor tissue can also be used as a scaffold instead of synthetic material [9] and recellularised with a autologous stem cells and used in clinical transplantation of air ways in patients with long segmental congenital tracheal stenosis [10-12]. Clinical application of a scaffolds guided tissue engineering vascular construct was reported in 2001 for patients with single ventricle [13]. Tissue engineered conduits are used in 25 patients in a low pressure environment with only two late cardiac failure and deaths. These conduits were used as extra cardiac cavo pulmonary connections $[14,15]$.

3D scaffolds advantages over 2D are that 3D are more relevant cell model, better simulation of conditions in a living organisms with integrations of flow and good interaction of 
various types of cells. MSCS are also present in muscles [16] adipose tissue [17], scalp [18], and olfactory mucosd tissue [19]. Commonly used materials are polyglycolide (PGA) [20,21] polylactide (PLA) [22,23] and polglycolide (PLGA) [24,25] and polycaproactone (PCL) [26,27]. Naturally occurring polymers useful in tissue engineering are collagen $[28,29]$ gelatin $[30,31]$ fibrin [32] and algininate [33] Hard tissue engineering scaffolds needs the material like $\beta$ tricalcium phosphate (TCP) and hydroxy apatite (HAP) [34] for bone formation.

It is now evident that cell seeded on $3 \mathrm{~d}$ scaffolds emerge as a vehicle for improved oxygen support and also to deliver relevant therapeutic agents to facilitate tissue function and to regenerated damaged or otherwise compromised tissue function $[35,36]$.

\section{Conclusion}

Future prospective studies on tissue engineering creating appropriate scaffolds and good micro environment with culture and growth factors with the development of novel methods are the hope for therapeutic applications. The pliability of 3D scaffolds can active signaling pathways than 2D scaffolds. Novel methods like increasing the oxygen supply with fluorinated molecules and calcium peroxide increases the oxygen delivery into the scaffolds and cells. Newer methods of acceleration of perfusion and cellular integration for effective drug delivery may be the future hope for excellent clinical results.

\section{References}

1. Yang C, Tristan IC, Justin GL, Bernard ET, Justin JCW (2005) Australian Journal of Chemistry 8: 691-703.

2. Arinzeh TL (2005) Biomaterials 26: 3631.

3. Elliott MJ, De Coppi P, Speggiorin S, Roebuck D, Butler CR, et al. (2012) Stem-cell-based, tissue engineered tracheal replacement in a child: a 2-year follow-up study. Lancet 380(9846): 994-1000.

4. Macchiarini P, Walles T, Biancosino C, Mertsching H (2004) First human transplantation of a bioengineered airway tissue. J Thorac Cardiovasc Surg 128(4): 638-641.

5. Macchiarini P, Jungebluth P, Go T (2008) Clinical transplantation of a tissue-engineered airway. Lancet 372(9655): 2023-2030.

6. Shin'oka T, Imai Y, Ikada Y (2001) Transplantation of a tissue engineered pulmonary artery. N Engl J Med 344(7): 532-533.

7. Hibino N, McGillicuddy E, Matsumura G, Ichihara Y, Naito Y, et al. (2010) Late-term results of tissue-engineered vascular grafts in humans. J Thorac Cardiovasc Surg 139(2): 431-436.

8. Duncan DR, Breuer CK (2011) Challenges in translating vascular tissue engineering to the pediatric clinic. Vasc Cell 3(1): 23.

9. Sun JS, Wu SY, Lin Y (2005) The role of muscle-derived stem cells in bone tissue engineering. Biomaterials 26(18): 3953-3960.

10. Gimble JM, Katz AJ, Bunnell BA (2007) Adipose-derived stem cells for regenerative medicine. Stem Cells 100(9): 1249-1260.

11. Shih DT, Lee DC, Chen SC, Tsai RY, Huang CT (2005) Isolation and characterization of neurogenic mesenchymal stem cells in human scalp tissue. Stem Cells 23(7): 1012-1020.

12. Wayne M, François F, Andrew W, Nick C (2005) Multipotent stem cells from adult olfactory mucosa. Developmental Dynamics 233(2): 496515.
13. Goldstein BJ, Goss GM, Choi R, Saur D, Seidler B (2016) Contribution of Polycomb group proteins to olfactory basal stem cell self-renewal in a novel c-KIT+ culture model and in vivo. Development 143(23): 43944404.

14. Freed LE, Vunjak Novakovic G, Biron RJ, Eagles DB, Lesnoy DC, et al. (1994) Biodegradable polymer scaffolds for tissue engineering. Biol Technology 12: 689.

15. Mikos AG, Bao Y, Cima LG, Ingber DE, Vacanti JP, et al. (1993) Preparation of poly(glycolic acid) bonded fiber structures for cell attachment and transplantation. J Biomed Mater Res 27: 183.

16. Agrawal CM, Ray RB (2001) Biodegradable polymeric scaffolds for musculoskeletal tissue engineering. J Biomed Mater Res 55: 141.

17. Schugens C, Grandfils C, Jerome R, Teyssie P, Delree P, et al (1995) Polylactide macroporous biodegradable implants for cell transplantation. II. Preparation of polylactide foams by liquid-liquid phase separation. J Biomed Mater Res 29: 1349.

18. Singhal AR, Agarwal CM, Athanasiou KA (1996) Salient Degradation Features of a 50:50 PLA/PGA Scaffold for Tissue Engineering. Tissue engineering 2: 207.

19. Holy CE, Shoichet MS, Davies JE (1998) Proc $24^{\text {th }}$ meet society for biomaterials. SFB: Mt Laurel, NJ, USA, p. 125.

20. Samaresh G, Ajit K (2004) Biocompatibility and antibacterial activity studies of polyamidoamine (PAMAM) dendron, side chain dendritic oligourethane (SCDOU). Biomed Research 71(1): 1-189.

21. Cao Y, Croll TI, Cooper White JJ, O'Connor AJ, Stevens GW (2004) Biopolymer methods in tissue engineering. In: Hollander AP, Hatton PV (Eds.), Humana, Totowa, NJ, USA, p. 400.

22. Yang A, Tristan I, Justin GB, Bernard E, Tuch B, et al. (2000) Scaffolds, stem cells, and tissue engineering: a potent combination!

23. Cassell O, Morrison W, Messina A, Penington A, Thompson E, et al. (2001) Academy of Sciences 944: 429.

24. Cronin KJ, Messina A, Knight KR, Cooper White JJ, Stevens GW, et al. (2004) New murine model of spontaneous autologous tissue engineering, combining an arteriovenous pedicle with matrix materials. Plast Reconstr Surg 113(1): 260-269.

25. Corden TJ, Jones IA, Rudd CD, Christian P, Downes S (2000) Physical and biocompatibility properties of poly-epsilon-caprolactone produced using in situ polymerisation: a novel manufacturing technique for longfibre composite materials. Biomaterials 21(7): 713-724.

26. Zein I, Hutmacher DW, Tan KC, Teoh SH (2002) Fused deposition modeling of novel scaffold architectures for tissue engineering applications. Biomaterials 23(4): 1169-1185.

27. Besseau B, Coulomb B, Lebreton C, Giaraud Guille MM (2002) Production of ordered collagen matrices for three-dimensional cell culture. Biomaterials 23: 27-36.

28. Heimburg DV, Zacharaih S, Heschel I, Kuhling H, Schoof H, et al. (2001) Biomaterials 22: 429.

29. Hutmacher DW, Goh JCH (2001) Annals of the Academy of Medicine 30: 183 .

30. Kosmala JD, Henthorn DB, Brannon L (2000) Preparation of interpenetrating networks of gelatin and dextran as degradable biomaterials. Biomaterials 21(20): 2019-2023.

31. Bensaïd W, Triffitt JT, Blanchat C, Oudina K, Sedel L, et al. (2003) A biodegradable fibrin scaffold for mesenchymal stem cell transplantation. Biomaterials 24(14): 2497-2502.

32. A biodegradable fibrin scaffold for mesenchymal stem cell transplantation. Biomaterials 24: 2497-2502. 
33. Eiselt P, Yeh J, Latvala RK, Shea LD, Mooney DJ (2000) Porous carriers for biomedical applications based on alginate hydrogels. Biomaterials 21(19): 1921-1927.

34. Shapiro L, Cohen S (1997) Novel alginate sponges for cell culture and transplantation. Biomaterials 18: 583-590.

This work is licensed under Creative Commons Attribution 4.0 License DOI: $10.19080 / C T B E B .2018 .15 .555920$
35. Arinzeh TL, Tran T, Mcalary J, Daculsi G (2005) A comparative study of biphasic calcium phosphate ceramics for human mesenchymal stemcell-induced bone formation. Biomaterials 26(16): 3631-3638.

36. Tlemey GB, Dawit G, Kibrel M (2013) Scaffolds in tissue engineering and regenerative medicine: beyond structural template pharm. Bioprocess 1(3): 267-281.

\section{Your next submission with Juniper Publishers} will reach you the below assets

- Quality Editorial service

- Swift Peer Review

- Reprints availability

- E-prints Service

- Manuscript Podcast for convenient understanding

- Global attainment for your research

- Manuscript accessibility in different formats ( Pdf, E-pub, Full Text, Audio)

- Unceasing customer service

Track the below URL for one-step submission https://juniperpublishers.com/online-submission.php 